American Journal of Economics and Business Administration 2 (3): 232-239, 2010

ISSN 1945-5488

(C) 2010 Science Publications

\title{
When is Inflation Harmful? Estimating the Threshold Effect for Ghana
}

\author{
${ }^{1}$ Joseph Magnus Frimpong and ${ }^{2}$ Eric Fosu Oteng-Abayie \\ ${ }^{1}$ Department of Accounting and Finance, \\ ${ }^{2}$ Department of Economics, \\ Kwame Nkrumah University of Science and Technology, Kumasi, Ghana
}

\begin{abstract}
Problem statement: Is inflation harmful? At what level? For all countries, both developed and developing, one of the fundamental objectives of macroeconomic policy is macroeconomic stability. In Ghana monetary and fiscal policies are aimed at sustaining high economic growth rates together with low inflation (price stability). Approach: This study estimated the threshold effect of inflation in Ghana for the period 1960-2008 using threshold regression models designed to estimate the inflation thresholds instead of imposing them. Results: We found evidence of a threshold effect of inflation on economic growth in Ghana. The result indicates inflation threshold level of $11 \%$ at which inflation starts to significantly hurt economic growth in Ghana. Below the $11 \%$ level, inflation is likely to have a mild effect on economic activities, while above this threshold level, inflation would adversely affect economic growth. Conclusion: The study concluded that the current medium term inflation target of 6-9\% annual average set by the Bank of Ghana and the Government respectively is well below the $11 \%$ threshold is in the right direction.
\end{abstract}

Key words: Ghana, inflation, growth, threshold effect

\section{INTRODUCTION}

For all countries, both developed and developing, one of the fundamental objectives of macroeconomic policy is economic stability. In Ghana monetary and fiscal policies are aimed at sustaining high economic growth rates together with low inflation (price stability). Having formally adopted inflation targeting framework for monetary policy, Ghana has been targeting single digit average inflation rate of 7-9\% annually, though this has consistently been missed.

Theoretical and empirical studies give diverse conclusions regarding the direction of impact of inflation on economic growth. High inflation is known to have many adverse effects: it imposes welfare costs on society, impedes efficient resource allocation by obscuring the signaling role of relative price changes, inhibits financial development by making intermediation more costly, hits the poor excessively because they do not hold financial assets that provide a hedge against inflation, reduces a country's international competitiveness, by making its exports relatively more expensive, thus impacting negatively on the balance of payment and perhaps most importantly, reduces long-term economic growth (Feldstein, 1982; Ocran, 2007; Khan and Senhadji, 2001). Moreover, inflation can interact with the tax system to distort borrowing and lending decisions, raise the cost of capital, so discouraging investment and hence growth (Feldstein, 1982).

On the other hand, there is general consensus from the literature that moderate inflation also helps in economic growth (Mubarik, 2005). Inflation can induce short run growth through expansionary macroeconomic policies, but this effect is not sustainable in the long run. In the long run, the relationship between inflation and growth is undoubtedly negative Barro (1995); Fischer (1993) and Bruno and Easterly (1998).

Drukker et al. (2005) categorizes four principal predictions in the literature regarding the impact of inflation on output and growth. (1) The prediction that there is no effect of inflation on growth (money is super-neutral) (Sidrauski, 1967); (2) Tobin (1965) assumption that money is a substitute for capital, causing inflation to have a positive effect on long-run growth; (3) Stockman (1981) cash-in-advance model in which money is complementary to capital, causing inflation to have a negative effect on long-run growth; (4) Huybens and Bruce (1998) new class of models in which inflation has a negative effect on long-run growth, but only if the level of inflation is above a threshold level. In this class of models, financial market efficiency is affected by various informational

Corresponding Author: Joseph Magnus Frimpong, Department of Accounting and Finance,

Kwame Nkrumah University of Science and Technology, Ghana 
asymmetries. For example, high rates of inflation typically exacerbate financial market frictions, interfere with the efficiency of the financial system and thus inhibit growth. Huybens and Bruce (1998) predictions ask the fundamental question 'what level of inflation should countries target for?' "Single digits are at first pass a useful rule of thumb" (Khan, 2005). The implication is that there is a non-linear relationship between inflation and economic growth.

There is a plethora of studies based on the first three predictions in the extant empirical literature. For instance, in Ghana studies by Sowa and Kwakye (1994) and Ocran (2007) concentrated on finding evidence in support of the first three predictions. They studied the impact of inflation on economic growth in Ghana to find the direction of the effect of inflation on economic growth.

Following Drukker et al. (2005), we provide evidence that there is a threshold level of inflation above which the effect of inflation is negative and statistically significant in Ghana and we interpret our result as supporting prediction 4 . Thus the study goes beyond the works of Sowa (1996) and Ocran (2007) by extending the analysis to the estimation of the threshold effect of inflation on economic growth in Ghana for the period 1965-2008. The study has the following key objectives to achieve: (1) estimate the threshold level of inflation rate beyond which inflation can be harmful to economic growth in Ghana and (2) draw macroeconomic policy implications.

Though both monetary and fiscal policies in Ghana are targeted at reducing inflation to single digits, there is no empirical answer to the question regarding the threshold level above which inflation is considered harmful. An answer to this question will go a long way in guiding policy makers in choosing appropriate inflation targets to improve macroeconomic management of Ghana's economy.

The next section reviews the theoretical and empirical literature followed by a description of the materials and methods used. The discussion of the results and the conclusion are finally presented.

Empirical evidence on threshold effect of inflation on growth: The extant empirical literature on threshold effect (nonlinear) of inflation on economic growth is dominated by cross-country panel studies. Sarel (1996); Ghosh and Phillips (1998); Khan and Senhadji (2001) and Khan (2005) are classical examples. These crosscountry studies were justified based on their ability to generalize empirical findings and their strong policy implication appeal. On the other hand, due to the heterogeneous factors pertaining in different countries, specific country studies can provide specific evidence relevant for the country under study. Such is one of the motivations for this study.

Bruno and Easterly (1998) examine the determinants of economic growth using annual CPI inflation of 26 countries which experienced inflation crises during the period between 1961 and 1992. The empirical findings of the study indicate the existence of threshold level of inflation rate of $40 \%$. Thus, inflation rate of $40 \%$ and over is considered as the threshold level for an inflation crisis. They find inconclusive relationship between inflation and economic growth below this threshold level when countries with high inflation crisis are excluded from the sample. In addition, the empirical analysis suggests that there exists a temporal negative relationship between inflation and economic growth beyond this threshold level. The robustness of the empirical results is examined by controlling for other factors such as shocks (examples are political crises, wars and terms of trade).

They also find that countries that have crossed the threshold into high inflation (and a negative effect on economic growth) experience a surprisingly strong recovery in growth once inflation falls back below the threshold. This suggests that there is no permanent damage to economic growth due to discrete high inflation crises.

Boyd et al. (2001) examine five-year average data on bank credit extension to the private sector, the volume of bank liabilities outstanding, stock market capitalization and trading volume (all as ratios to GDP) and inflation for a cross-sectional sample over 19601995. Boyd et al. (2001) finds that, at low-to-moderate rates of inflation, increases in the rate of inflation lead to markedly lower volumes of bank lending to the private sector, lower levels of bank liabilities outstanding and significantly reduced levels of stock market capitalization and trading volume.

In addition, Boyd et al. (2001) finds that the relationship between inflation and financial development is nonlinear. That is, a given percentagepoint increase in the rate of inflation has a much larger effect on financial development at low than at high rates of inflation. However, Boyd et al. (2001) did not estimate the exact threshold level. They experimented with critical values ranging from a $7.5-40 \%$ inflation rate and then chose a $15 \%$ inflation rate as representative.

Sarel (1996) makes use of data on population, GDP, consumer price indices, terms of trade, real exchange rates, government expenditures and 
investment rates. A joint panel database was produced combining continuous annual data from 87 countries, during the period from 1970-1990. The empirical findings give evidence of the existence of a structural break that is significant. The break is estimated to occur when the inflation rate is $8 \%$. Below that rate, inflation does not have any effect on growth or it may even have slightly positive effect. However, when the inflation is above $8 \%$, inflation effect on growth is estimated to be significantly negative and robust. The results suggest a specific numerical target policy: Keep inflation below the $8 \%$.

Khan and Senhadji (2001) examine the issue of existence of threshold effects in the relationship between inflation and growth, using econometric techniques originally developed by Kung-Sig and Tsay (1998) and Hansen (1999; 2000). They used data set from 140 countries (comprising both industrialized and developing countries) and generally covered the period from 1960-1998. Due to non-availability of some data for some developing countries, the analysis was conducted by them using 'unbalanced panel'.

The empirical results suggest the existence of threshold beyond which inflation-growth relationship becomes negative. Inflation rates below the threshold level have no effect on growth, while inflation rates above the threshold have significant negative effect on growth. The empirical results estimate threshold levels of 1-3 and 7-11\% for industrialized and developing countries respectively. The results clearly suggest that the threshold is lower for industrialized countries than it is for developing countries.

Kremer et al. (2009) provides new evidence on the effect of inflation on long-term economic growth for a panel of 63 industrial and non-industrial countries. The empirical results show that inflation impedes growth if it exceeds thresholds of $2 \%$ for industrial and $12 \%$ for non-industrial countries, respectively. The study, however, indicates that below these thresholds, the effects of inflation on growth are significantly positive.

According to Kemer et al. (2009), inflation thresholds in developing countries and, thus, the appropriate level of the inflation target might be country-specific. Kemer et al. (2009) recommends that the identification of country-specific inflation thresholds in the inflation-growth nexus might provide useful information about the appropriate location and width of an inflation targeting band. Several specific country studies identified in the literature includes Hodge (2005) for South Africa, Fabayo and Ajilore (2006) for Nigeria, Sargsyan (2005) for Armenia and Kheir-El-Din and Abou-Ali (2008) for Egypt.
Hodge (2005) studies the relationship between inflation and growth in South Africa. Two main issues were addressed: Do tests of the South African data support the findings of cross-section studies that inflation has a negative effect on growth over the longer term? and, can higher growth be gained at the cost of higher inflation in the short run? The findings were that inflation drags down growth in South Africa over the longer term and that, in the short run, growth above its trend requires accelerating inflation. Thus, for growth to be pulled substantially above its then present low trend, inflation targeting in South Africa would have to be abandoned. However, this would be counterproductive over the longer term, once the negative relationship between inflation and growth manifests itself.

Fabayo and Ajilore (2006) follow the methodology of Khan and Sendhaji (2001) to examine the existence of threshold effects in inflation-growth relationship using Nigeria data for the period 1970-2003. The results suggest the existence of inflation threshold level of $6 \%$. Below this level, there exists significantly positive relationship between inflation and economic growth, while above this threshold level, inflation retards growth performance. Sensitivity analyses conducted confirmed the robustness of these results. This finding suggests that bringing inflation down to single digits should be the goal of macroeconomic management in Nigeria and accordingly the optimal inflation target for policy in Nigeria is $6 \%$.

Kheir-El-Din and Abou-Ali (2008) addresses the relationship between inflation and growth in Egypt for the last quarter century. Two distinct sub-periods were observed: Somewhat higher and more volatile GDP growth rate is associated with higher inflation prior to 1990/1991; from this year onwards, lower and less volatile growth is associated with significantly lower inflation. It was found that the impact of inflation on GDP growth is not significantly different between the two periods. Testing for non-linear effects of inflation on growth in Egypt, it appears that there is no threshold of inflation, beyond which it is harmful to growth. To the contrary, the findings suggest that inflation at any level negatively impacts economic growth. It is thus beneficial to focus monetary policy towards maintaining price stability.

This study examines the relationship between inflation and output growth in Armenia. The study tested for a threshold level of inflation at which the effect of inflation on growth changes from negative to positive, as inflation passes that level. The threshold level of inflation was calculated using Khan and Sendhaji (2001) econometric technique. The study concludes that for the Armenian economy targeting a level of inflation higher than current $3 \%$ but not 
exceeding $4.5 \%$ threshold level might be beneficial for growth in Armenia.

\section{MATERIALS AND METHODS}

Threshold Regression model: The threshold regression model is developed by Khan and Senhadji (2001) for the analysis of the threshold level of inflation. This study utilizes the threshold regression model to estimate the threshold level of inflation above which inflation affects economic growth for Ghana. We estimate the coefficients and number of threshold points in the functional form specified in Eq. 1:

$$
\dot{\mathrm{Y}}_{\mathrm{t}}=\alpha_{0}+\beta_{1} \dot{\mathrm{P}}_{\mathrm{t}}+\beta_{2} \mathrm{D}_{\mathrm{t}}\left(\dot{\mathrm{P}}_{\mathrm{t}}-\kappa\right)+\beta_{2+\mathrm{i}} \mathrm{X}_{\mathrm{it}}+\mu
$$

Where, economic growth and inflation are computed as: $\dot{\mathrm{Y}}=\Delta \ln \left(\mathrm{Y}_{\mathrm{t}}\right)$

$\dot{\mathrm{P}}=\Delta \ln \left(\mathrm{P}_{\mathrm{t}}\right)$

$\mathrm{Y}_{\mathrm{t}}=$ Real GDP

$\dot{\mathrm{Y}}_{\mathrm{t}}=$ Growth rate of real GDP

$\mathrm{P}_{\mathrm{t}}=$ Consumer price index

$\dot{\mathrm{P}}_{\mathrm{t}}=$ Inflation

$\kappa=$ The threshold level of inflation

$\mu_{\mathrm{i}}=$ The random term which represents measurement error in the explanatory variables

The variable $X_{i t}$ is a vector of control variables which include the growth rate of gross domestic investment as a proportion of GDP $\left(\mathrm{I}_{\mathrm{t}}\right)$, growth rate of aggregate labor force $\left(\mathrm{L}_{\mathrm{t}}\right)$, the growth rate of terms of trade $\left(T_{t}\right)$ and the growth rate of money supply $\left(M_{t}\right)$. The growth rates of all these explanatory variables are computed using similar method as $\dot{\mathrm{Y}}_{\mathrm{t}}$ and $\dot{\mathrm{P}}_{\mathrm{t}}$. The dummy variable $\mathrm{D}_{\mathrm{t}}$ is defined in the following way:

$\mathrm{D}_{\mathrm{t}}=\{1\}:$ if $\dot{\mathrm{P}}_{\mathrm{t}}>\kappa$ and $\{0\}:$ if $\dot{\mathrm{P}}_{\mathrm{t}} \leq \kappa$

As per the definition in Mubarik (2005) the parameter $\mathrm{K}$ (that is the threshold inflation level) has a property that the relationship between economic growth and inflation is given by: (i) $\beta_{1}$ represents low inflation; (ii) $\left(\beta_{1}+\beta_{2}\right)$ represents high inflation. The high inflation means that when the long-run inflation estimate is significant then both coefficients $\left(\beta_{1}+\beta_{2}\right)$ would be added to see their impact on growth and that would be the threshold level of inflation.

By estimating regressions for different values of $\mathrm{k}$ which is chosen in an ascending order (that is 1, 2, 3 and so on), the optimal value of $\mathrm{k}$ is obtained by finding the value that maximizes the $\mathrm{R}^{2}$ from the respective regressions. In other words, the optimal threshold level $\left(\mathrm{k}^{*}\right)$ is that which minimizes the Residual Sum of Squares (RSS). The lack of knowledge of the optimal number of threshold points and their values complicates estimation and inference. Though the procedure is widely accepted in the empirical literature, it is tedious since several regressions have to be estimated. Khan and Senhadji (2001) discuss the details of the estimation procedure and the computation methods.

Data: We use annual data set for the period of 19602008 from the World Bank (2009) and the Bank of Ghana Quarterly Digest of Statistics.

\section{RESULTS AND DISCUSSION}

A graphical presentation of the inflation-growth relationship: Figure 1 illustrates the trend in inflation and real GDP growth rates of Ghana from 1960-2006. It portrays an inverse relationship between the two macroeconomic variables. As illustrated, growth rates remained generally low and some instances negative, in the late 1970s and early 1980s when the inflation rates were very high. However, economic growth has consistently remained steady and relatively high with an annual average rate of $4.5 \%$ from 1983 through 2000 , but accelerated to $5.8 \%$ in 2004 and $6.2 \%$ in 2006 , when inflation rates are relatively moderate.

To understand the historical nature of the relationship between inflation and economic growth in Ghana more accurately, the study follows the analysis approach adopted by Mubarik (2005). With this approach, the whole sample covering 1960-2008 is grouped into 8 observations. First of all, a range of inflation is chosen from the sample minimum and maximum levels of inflation rates. For example, if inflation is $5 \%$ or less, it is associated at level 5. In much the same way, if inflation rate is more than $5 \%$

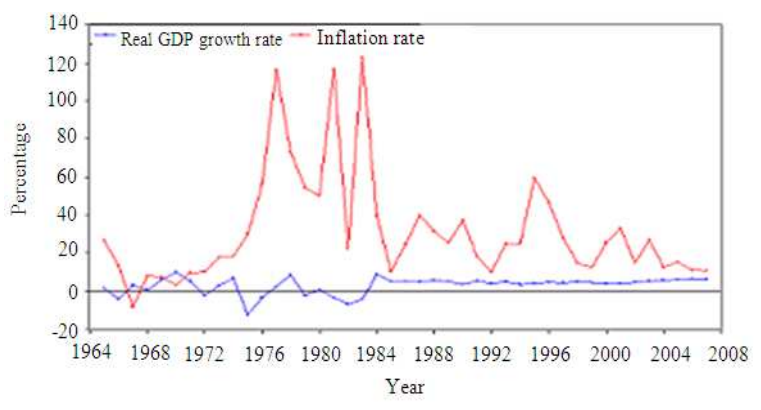

Fig. 1: Inflation and real GDP growth rates 1965-2007 


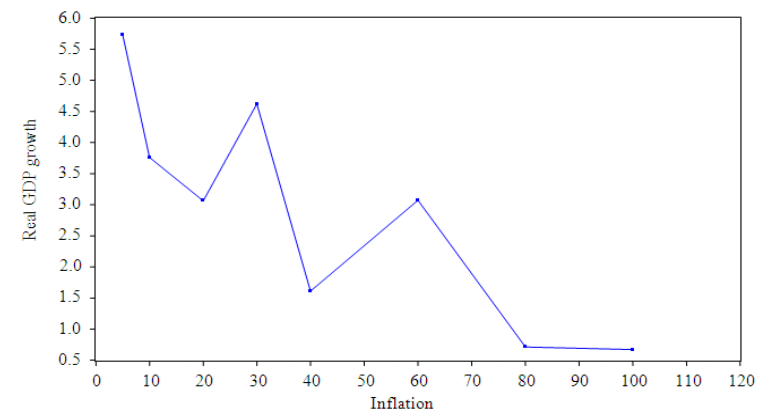

Fig. 2: Average GDP growth liner level inflation but less than or equal to $10-\%$, it is assigned level 10 and so on. Within each band (range) of inflation, average real GDP growth rates are calculated against each linear level of inflation. For illustration, the range of inflation rate of $5 \%$ or less, which is assigned level 5, has an average real GDP growth rate of $5.73 \%$ during the period of 1965-2007. In this context, Fig. 2 illustrates largely a negative relationship between inflation and real GDP growth. This simple analysis suggests that inflation has a negative effect on economic growth.

Table 1: Estimation of inflation threshold model at $\mathrm{K}=6-\mathrm{K}=12$

\begin{tabular}{|c|c|c|c|c|c|c|c|}
\hline Percent & Variable & Coefficient & Std. Error & $\mathrm{t}$-Statistic & Prob. & $\mathrm{R}^{2}$ & DW \\
\hline \multirow{5}{*}{6} & $\dot{\mathrm{P}}_{\mathrm{t}}$ & -0.382051 & 0.169667 & -2.251766 & 0.0302 & \multirow{5}{*}{0.359} & \multirow{5}{*}{1.9} \\
\hline & $\mathrm{D}(\dot{\mathrm{P}}-6)$ & 0.353711 & 0.173509 & 2.038579 & 0.0485 & & \\
\hline & $\dot{\mathrm{K}}$ & 0.063082 & 0.028335 & 2.226288 & 0.0320 & & \\
\hline & $\dot{\mathrm{T}}$ & 2.014484 & 0.713268 & 2.824300 & 0.0075 & & \\
\hline & $\mathrm{C}$ & 7.385053 & 1.039306 & 7.105756 & 0.0000 & & \\
\hline \multirow{4}{*}{7} & $\dot{\mathrm{P}}_{\mathrm{t}}$ & -0.375634 & 0.167726 & -2.239566 & 0.0310 & \multirow{4}{*}{0.364} & \multirow{4}{*}{1.94} \\
\hline & $\mathrm{D}(\dot{\mathrm{P}}-7)$ & 0.348004 & 0.171510 & 2.029059 & 0.0495 & & \\
\hline & $\dot{\mathrm{K}}$ & 0.062878 & 0.028105 & 2.237223 & 0.0312 & & \\
\hline & $\begin{array}{c}\dot{\mathrm{T}} \\
\mathrm{C}\end{array}$ & $\begin{array}{l}2.046357 \\
7.695618\end{array}$ & $\begin{array}{l}0.709454 \\
1.182321\end{array}$ & $\begin{array}{l}2.884413 \\
6.508905\end{array}$ & $\begin{array}{l}0.0064 \\
0.0000\end{array}$ & & \\
\hline \multirow{5}{*}{8} & $\dot{\mathrm{P}}_{\mathrm{t}}$ & -0.379136 & 0.168602 & -2.248702 & 0.0304 & \multirow{5}{*}{0.367} & \multirow{5}{*}{1.95} \\
\hline & $\mathrm{D}(\dot{\mathrm{P}}-8)$ & 0.352745 & 0.172370 & 2.046436 & 0.0477 & & \\
\hline & $\dot{\mathrm{K}}$ & 0.062552 & 0.027817 & 2.248720 & 0.0304 & & \\
\hline & $\dot{\mathrm{T}}$ & 2.104755 & 0.706163 & 2.980552 & 0.0050 & & \\
\hline & $\mathrm{C}$ & 8.077559 & 1.346518 & 5.998851 & 0.0000 & & \\
\hline \multirow{4}{*}{9} & $\dot{\mathrm{P}}_{\mathrm{t}}$ & -0.380915 & 0.170685 & -2.231692 & 0.0316 & \multirow{4}{*}{0.372} & \multirow{4}{*}{1.97} \\
\hline & $\mathrm{D}(\dot{\mathrm{P}}-9)$ & 0.356140 & 0.175010 & 2.034970 & 0.0489 & & \\
\hline & $\dot{\mathrm{K}}$ & 0.061958 & 0.027489 & 2.253898 & 0.0301 & & \\
\hline & $\begin{array}{l}\dot{\mathrm{T}} \\
\mathrm{C}\end{array}$ & $\begin{array}{l}2.185640 \\
8.459334\end{array}$ & $\begin{array}{l}0.717153 \\
1.528385\end{array}$ & $\begin{array}{l}3.047664 \\
5.534818\end{array}$ & $\begin{array}{l}0.0042 \\
0.0000\end{array}$ & & \\
\hline \multirow{5}{*}{10} & $\dot{\mathrm{P}}_{\mathrm{t}}$ & -0.382932 & 0.170853 & -2.241293 & 0.0309 & \multirow{5}{*}{0.378} & \multirow{5}{*}{1.98} \\
\hline & $\mathrm{D}(\dot{\mathrm{P}}-10)$ & 0.359934 & 0.175714 & 2.048414 & 0.0475 & & \\
\hline & $\dot{\mathrm{K}}$ & 0.061312 & 0.027176 & 2.256090 & 0.0299 & & \\
\hline & $\dot{\mathrm{T}}$ & 2.274523 & 0.729499 & 3.117923 & 0.0035 & & \\
\hline & $\mathrm{C}$ & 8.850701 & 1.702164 & 5.199675 & 0.0000 & & \\
\hline \multirow{5}{*}{11} & $\dot{\mathrm{P}}_{\mathrm{t}}$ & -0.388870 & 0.175010 & -2.221983 & 0.0323 & \multirow{5}{*}{$0.384 *$} & \multirow{5}{*}{2.01} \\
\hline & $\mathrm{D}(\dot{\mathrm{P}}-11)$ & 0.368624 & 0.180904 & 2.037673 & 0.0486 & & \\
\hline & $\dot{\mathrm{K}}$ & 0.061678 & 0.027219 & 2.265980 & 0.0292 & & \\
\hline & $\dot{\mathrm{T}}$ & 2.365554 & 0.748628 & 3.159853 & 0.0031 & & \\
\hline & $\mathrm{C}$ & 9.234200 & 1.891106 & 4.882962 & 0.0000 & & \\
\hline \multirow{5}{*}{12} & $\dot{\mathrm{P}}_{\mathrm{t}}$ & -0.011981 & 0.314704 & -0.038071 & 0.9698 & \multirow{5}{*}{0.334} & \multirow{5}{*}{1.99} \\
\hline & $\mathrm{D}(\dot{\mathrm{P}}-12)$ & -0.026019 & 0.327272 & -0.079502 & 0.9371 & & \\
\hline & $\dot{\mathrm{K}}$ & 0.059329 & 0.027654 & 2.145397 & 0.0384 & & \\
\hline & $\dot{\mathrm{T}}$ & 1.618149 & 0.874252 & 1.850895 & 0.0720 & & \\
\hline & $\mathrm{C}$ & 5.061438 & 3.895570 & 1.299281 & 0.2017 & & \\
\hline
\end{tabular}

*: $\mathrm{R} 2$ is maximized. Dependant Variable is $\dot{\mathrm{Y}}$ 
Estimation of inflation threshold: Following conclusions from the extant literature, we hypothesize that high inflation in Ghana has an adverse effect on economic growth after it exceeds a certain limit. Moreover, using Khan and Senhadji (2001) estimated inflation threshold level of between 7 and $11 \%$ for developing countries and the single digit inflation target (of 6-9\%) set by the Bank of Ghana as benchmarks, we estimate for the threshold level within 6 and $12 \%$ range. A sensitivity analysis is also performed to validate the initial results.
The estimation of Eq. 1 gives a specific value of the threshold inflation level and also measure the impact of that level on economic growth. Equation 1 was estimated to maximize the coefficient of determination $\left(\mathrm{R}^{2}\right)$ for each threshold level of inflation ranging from $\mathrm{K}=6-\mathrm{K}=12$ is computed. Table 1 reports the results of the estimation of the inflation threshold levels and Table 1 is reports the sensitivity analysis.

From Table 1, the results show inflation threshold level of $11 \%$ at which the R2 is maximized. At $11 \%$ threshold level of inflation, the coefficient of $\mathrm{D}\left(\mathrm{P}_{\mathrm{t}}-11\right)$

\begin{tabular}{|c|c|c|c|c|c|c|c|}
\hline K & Variable & Coefficient & Std. Error & t-Statistic & Prob. & $\mathrm{R}^{2}$ & DW \\
\hline \multirow{5}{*}{$6 \%$} & $\dot{\mathrm{P}}_{\mathrm{t}}$ & -0.405144 & 0.183417 & -2.208873 & 0.0335 & \multirow{5}{*}{0.362} & \multirow{5}{*}{1.91} \\
\hline & $\mathrm{D}(\dot{\mathrm{P}}-6)$ & 0.378371 & 0.187960 & 2.013037 & 0.0514 & & \\
\hline & $\dot{\mathrm{K}}$ & 0.062826 & 0.028380 & 2.213747 & 0.0331 & & \\
\hline & $\dot{\mathrm{T}}$ & 2.176282 & 0.830254 & 2.621225 & 0.0126 & & \\
\hline & $\mathrm{C}$ & 7.586114 & 1.149282 & 6.600743 & 0.0000 & & \\
\hline \multirow{4}{*}{$7 \%$} & $\dot{\mathrm{P}}_{\mathrm{t}}$ & -0.398258 & 0.180525 & -2.206108 & 0.0337 & \multirow{4}{*}{0.366} & \multirow{5}{*}{1.92} \\
\hline & $\mathrm{D}(\dot{\mathrm{P}}-7)$ & 0.372279 & 0.184982 & 2.012514 & 0.0515 & & \\
\hline & $\dot{\mathrm{K}}$ & 0.062590 & 0.028140 & 2.224246 & 0.0323 & & \\
\hline & $\dot{\mathrm{T}}$ & 2.215107 & 0.825598 & 2.683032 & 0.0108 & & \\
\hline \multirow{5}{*}{$8 \%$} & $\begin{array}{l}\mathrm{C} \\
\dot{\mathrm{P}}\end{array}$ & $\begin{array}{r}7.920436 \\
-402032\end{array}$ & $\begin{array}{l}1.299549 \\
0.180959\end{array}$ & $\begin{array}{r}6.094 / 55 \\
-2226648\end{array}$ & $\begin{array}{l}0.0000 \\
0.0321\end{array}$ & \multirow{5}{*}{0.371} & \\
\hline & $\mathrm{D}(\dot{\mathrm{P}}-8)$ & 0.378372 & 0.185324 & 2.041674 & 0.0484 & & \multirow{4}{*}{1.93} \\
\hline & $\dot{\mathrm{K}}$ & 0.062219 & 0.027844 & 2.234589 & 0.0316 & & \\
\hline & $\dot{\mathrm{T}}$ & 2.287636 & 0.820716 & 2.787368 & 0.0083 & & \\
\hline & $\mathrm{C}$ & 8.340689 & 1.471670 & 5.667499 & 0.0000 & & \\
\hline \multirow{4}{*}{$9 \%$} & $\dot{\mathrm{P}}_{\mathrm{t}}$ & -0.407714 & 0.184325 & -2.211932 & 0.0332 & \multirow{4}{*}{0.377} & \multirow{4}{*}{1.95} \\
\hline & $\mathrm{D}(\dot{\mathrm{P}}-9)$ & 0.385078 & 0.189243 & 2.034835 & 0.0491 & & \\
\hline & $\dot{\mathrm{K}}$ & 0.061556 & 0.027508 & 2.237780 & 0.0313 & & \\
\hline & $\dot{\mathrm{T}}$ & $\begin{array}{l}2.391292 \\
8782312\end{array}$ & $\begin{array}{l}0.833225 \\
1677906\end{array}$ & $\begin{array}{l}2.869925 \\
5234090\end{array}$ & 0.0067 & & \\
\hline \multirow{5}{*}{$10 \%$} & $\dot{\mathrm{P}}_{\mathrm{t}}$ & -0.412931 & 0.185600 & -2.224843 & 0.0323 & \multirow{5}{*}{0.383} & \multirow{5}{*}{1.97} \\
\hline & $\mathrm{D}(\dot{\mathrm{P}}-10)$ & 0.392441 & 0.191038 & 2.054258 & 0.0471 & & \\
\hline & $\dot{\mathrm{K}}$ & 0.060823 & 0.027190 & 2.236927 & 0.0314 & & \\
\hline & $\dot{\mathrm{T}}$ & 2.506829 & 0.846021 & 2.963081 & 0.0053 & & \\
\hline & $\mathrm{C}$ & 9.243190 & 1.876839 & 4.924871 & 0.0000 & & \\
\hline \multirow{4}{*}{$11 \%$} & $\dot{\mathrm{P}}_{\mathrm{t}}$ & -0.423933 & 0.191733 & -2.211065 & 0.0333 & \multirow{4}{*}{$0.391 *$} & \multirow{4}{*}{2.01} \\
\hline & $\mathrm{D}(\dot{\mathrm{P}}-11)$ & 0.406794 & 0.198243 & 2.051993 & 0.0473 & & \\
\hline & $\dot{\mathrm{K}}$ & 0.061182 & 0.027252 & 2.245033 & 0.0308 & & \\
\hline & $\dot{\mathrm{T}}$ & $\begin{array}{l}2.633960 \\
9720767\end{array}$ & $\begin{array}{l}0.865823 \\
2.101825\end{array}$ & $\begin{array}{l}3.042147 \\
4624918\end{array}$ & 0.0043 & & \\
\hline \multirow{5}{*}{$12 \%$} & $\dot{\mathrm{P}}_{\mathrm{t}}$ & -0.025640 & 0.329097 & -0.077911 & 0.9383 & \multirow{5}{*}{0.333} & \multirow{5}{*}{1.95} \\
\hline & $\mathrm{D}(\dot{\mathrm{P}}-12)$ & -0.010988 & 0.343135 & -0.032024 & 0.9746 & & \\
\hline & $\dot{\mathrm{K}}$ & 0.059246 & 0.027671 & 2.141056 & 0.0389 & & \\
\hline & $\dot{\mathrm{T}}$ & 1.730319 & 1.045239 & 1.655429 & 0.1063 & & \\
\hline & $\mathrm{C}$ & 5.261201 & 4.111816 & 1.279532 & 0.2087 & & \\
\hline
\end{tabular}

*: $\mathrm{R}^{2}$ is maximized. Dependant Variable is; $\dot{\mathrm{Y}}$ : Dependant variable: $\dot{\mathrm{Y}}:$ Instrument list: $\dot{\mathrm{Y}}_{\mathrm{t}-1} \mathrm{D}(\dot{\mathrm{P}}-\kappa) \quad \dot{\mathrm{P}} \quad \dot{\mathrm{T}} \quad \dot{\mathrm{K}}$ 
is statistically significant at $5 \%$ level. This implies that if inflation increases beyond the $11 \%$ threshold level, economic growth would approximately change by the sum of the coefficients of $\dot{\mathrm{P}}_{\mathrm{t}}$ and $\Delta\left(\dot{\mathrm{P}}_{\mathrm{t}}-11\right)$, that is $\beta_{1}+\beta_{2}-0.023 \%$. In other words, if inflation increases above the $11 \%$ threshold, economic growth is expected to decline by about $0.02 \%$. Thus we can conclude that inflation should be kept below the $11 \%$ range to avoid the adverse growth effects. This finding is in line with Khan and Senhadji (2001) threshold range of $7-11 \%$ for developing countries.

Sensitivity analysis: To check the robustness and specification bias of the estimated model, the threshold model (of Eq. 1 is estimated again using the Two-Stage Least Squares (2SLS). The results of the 2SLS regression as produced in Table 2 also suggest $11 \%$ threshold inflation level. In estimating the threshold model, some other variables that can be found in growth literature were included in the initial model, but were dropped after producing insignificant results. These variables include growth rate of aggregate labor force and the growth rate of money supply.

The comparison of both estimated models, OLS (Table 1) and 2SLS (Table 2), indicate the same threshold level of inflation and close coefficients. Both models produce results that indicate an $11 \%$ threshold level of inflation for economic growth of Ghana.

However, looking closely at the results from both Table 1 and 2, even at relatively lower thresholds, inflation is still significant. This means that inflation could still harm growth even at lower levels between 6 and $10 \%$, though the impact may be minimal. Thus the natural extension to this study is to expand the analysis to deal lower threshold levels in search of that evidence.

\section{CONCLUSION}

Based on the approach adopted, we find some evidence that inflation has a threshold effect on economic growth. As an inflation targeting country, this is a crucial finding as it provides a baseline study in search of the optimal level of inflation for growth. We can palpably answer the question: what level of inflation is good for growth in Ghana? The implication for monetary policy is that it provide guide for policy makers to choose an optimal target for inflation and then designing the critical policies to achieve the target subsequently. With the current high inflation over and above the threshold it is not surprising that the government's broad economic and financial objectives for 2009 include: Real GDP growth of $5.9 \%$; reduced average inflation target of $15.3 \%$; end period reduced inflation of $12.5 \%$. Vividly, the high inflation is hurting growth.

In this light, the current medium term inflation target of $7 \%$ annual average set by the Bank of Ghana and the Government Budget respectively is well below the $11 \%$ threshold. In sum, current government policies, aimed at fostering fiscal discipline and reducing inflation hinged on prudent public expenditure management, strict adherence to public procurement rules, efficient and effective domestic revenue mobilization and encouraging the private sector to participate in our accelerated growth agenda through Public Private Partnerships (PPPs) must be pursued rigorously all things being equal.

\section{REFERENCES}

Barro, R., 1995. Inflation and economic growth. Bank of England Q. Bull., 166-176. http://papers.ssrn.com/sol3/papers.cfm?abstract_id $=225390$

Boyd, J.H., L. Ross and S. Bruce, 2001. The impact of inflation on financial sector performance. $\mathrm{J}$. Monetary Econ., 47: 221-248. http://ideas.repec.org/a/eee/moneco/v47y2001i2p2 21-248.html

Bruno, M. and W. Easterly, 1998. Inflation crises and long-run growth. J. Monetary Econ. 41: 3-26. http://ideas.repec.org/a/eee/moneco/v41y1998i1p326.html

Kung-Sig, C. and R.S. Tsay, 1998. Limiting properties of the least squares estimator of a continuous threshold autoregressive model. Biometrica, 85: 413-26.

http://biomet.oxfordjournals.org/cgi/content/abstra $\mathrm{ct} / 85 / 2 / 413$

Drukker, D., Gomis-Porqueras, P. and Hernandez-Verme, P. 2005. Threshold effects in the relationship between inflation and growth: A new panel-data approach. Proceedings of the 11th International Conference on Panel Data, Feb. 9. http://www.uh.edu/ cmurray/TCE/papers/Drukker. pdf

Fabayo, J.A. and O.T. Ajilore, 2006. Inflation-how much is too much for economic growth in Nigeria. Ind. Econ. Rev., 41: 129-148. http://ideas.repec.org/a/dse/indecr/v41y2006i2p129 $-147 . h \mathrm{tml}$

Feldstein, M., 1982. Inflation tax rules and investment: Some econometric evidence. Econometrica, 50: 825-62. http://www.jstor.org/pss/1912766 
Fischer, S. 1993. The role of macroeconomic factors in growth. J. Monetary Econ. 32: 48512. http://ideas.repec.org/p/nbr/nberwo/4565.html

Ghosh, A. and S. Phillips, 1998. Warning: Inflation may be harmful to your growth. IMF Staff Papers, 45: 672-710.

http://www.imf.org/external/Pubs/FT/staffp/1998/1 2-98/ghosh.htm

Hansen, B.E., 1999. Threshold effects in non-dynamic panels: Estimation, testing and inference. J. Econ., 93: 345-368. DOI: 10.1016/S0304-4076(99)00025-1

Hansen, B.E., 2000. Sample splitting and threshold estimation. Econometrica, 68: 575-603. http://www3.interscience.wiley.com/journal/11900 3353/abstract

Hodge, D., 2005. Inflation and growth in South Africa. Cambridge J. Econ., 30: 163-180. DOI: 10.1093/cje/bei051

Huybens, E. and D.S. Bruce, 1998. Financial market frictions, monetary policy and capital accumulation in a small open economy. J. Econ. Theory, 81: 353-400. http://ftp.itam.mx/pub/academico/inves/huybens/st abiliz.ps

Khan, M. and A. Senhadji, 2001. Threshold effects in the relationship between inflation and growth. IMF Staff Papers, 48: 1-21. http://ideas.repec.org/a/pal/imfstp/v48y2001i1p1.html

Khan, M., 2005. Inflation and Growth in MCD Countries. Mimeo. International Monetary Fund.

Kheir-El-Din, H. and H. Abou-Ali, 2008. Inflation and Growth in Egypt: Is There a Threshold Effect? ECES Working Paper No. 135. http://www.eces.org.eg/...7D_ECESWP-135.pdf

Kremer S., A. Bick and D. Nautz, 2009. Inflation and Growth: New Evidence From a Dynamic Panel Threshold Analysis. SFB 649 Discussion Paper 2009-036. http://sfb649.wiwi.hu-berlin.de/papers/

Mubarik, Y.A., 2005. Inflation and growth: An estimate of the threshold level of inflation in Pakistan. SBPRes. Bull., 1: 35-44. http://www.sbp.org.pk/research/bulletin/2005/Artic le-3.pdf
Ocran, M.K., 2007. A Modeling of Ghana's Inflation Experience: 1960-2003. AERC Research Paper No. 169. African Economic Research Consortium, Nairobi; www.aercafrica.org/documents/rp169.pdf

Sarel, M., 1996. Nonlinear effects of inflation on economic growth. IMF Staff Papers, 43: 199-215. http://papers.ssrn.com/sol3/papers.cfm?abstract_id $=883204$

Sargsyan, G.R., 2005. Inflation and output in Armenia: The threshold effect revisited. Proceeding of the 3rd International AIPRG conference on Armenia, Jan. 15-16, World Bank, Washington, DC. http://www.aiprg.net/UserFiles/File/jan2005/grigorsargsyan.pdf

Sidrauski, M., 1967. Inflation and economic growth. J. Political $\quad$ Econ., 75: 796-810. http://www.jstor.org/stable/1829572

Sowa, N.K., 1996. Policy Consistency and Inflation in Ghana. AERC Research Paper No. 43. African Economic Research Consortium, Nairobi., http://www.aercafrica.org/documents/rp43.pdf

Sowa, N.K. and J.K. Kwakye, 1994. Is Ghana's inflation a monetary phenomenon? Econ. Bull. Ghana, 22:1105-1117. DOI: 10.1016/0305750X(94)90079-5

Stockman, A., 1981. Anticipated inflation and the capital stock in a cash-in-advance economy. J. Monetary Econ., 8: 387-393. DOI: 10.1016/03043932(81)90018-0

Tobin, J., 1965. Money and economic growth. Econometrica, 33: 671-684. http://www.jstor.org/pss/1910352

World Bank, 2009. World development indicators. http://www.worldbank.org/data/wdi2009 